UDC 330

DOI: $10.31891 / 2307-5740-2021-298-5(1)-29$

WLADYSLAW WORNALKIEWICZ

The Academy of Management and Administration in Opole, Poland

YURII KRAVCHYK

ORCID ID: 0000-0002-2780-5605 e-mail: gromplus7@gmail.com

Khmelnytskyi National University

ALLA KAPLUNOVSKA

ORCID ID: 0000-0003-3734-1098

e-mail: allakaplunovska@gmail.com

Zaporizhia Polytechnic National University

\title{
THE OVERSIZED CARGO FORWARDING: ECONOMIC AND LEGAL ASPECTS
}

The transport of oversized cargo is becoming more and more popular, which is related to the construction of, inter alia, wind farms to generate electricity in mountain areas or on the coast of the Baltic Sea. Internet communication networks are expanding, thus requiring the construction of new relay towers. Non-divisible elements to be transported are getting longer and more difficult to be delivered and installed in the field. All this must be met by forwarding and transport of industrial long cargo. Such a situation requires specialized vehicles, monitoring and optimization of travel routes.

Keywords: oversized cargo, vehicle, semi-trailer, logistics systems, economic aspects, legal aspects.

ВОРНАЛКЕВІЧ ВЛАДИСЛАВ

Академія управління і адміністрації в Ополе, Польща

КРАВЧИК Ю. В.

Хмельницький національний університет

КАПЛУНОВСЬКА А. М.

НУ «Запорізька політехніка»

\section{ЕКСПЕДИЦІЯ НЕГАБАРИТНИХ ВАНТАЖІВ: ЕКОНОМІЧНІ ТА ЮРИДИЧНІ АСПЕКТИ}

Усі заходи, пов'язані з передачею матеріального блага, разом із усіма процесами планування та контролю передачі цього товару визначають поняття логістики. Важливо підтримувати логістичний процес за допомогою комп'ютерного програмного забезпечення, яке в основному базується на системі GPS. Одним із елементів процесу передачі товарів у логістиці $\epsilon$ транспортні послуги. Без транспортних послуг неможливо здійснити доставку.

Перевезення довгомірних вантажів здійснюється за допомогою транспортних засобів, конструкційно обладнаних для транспортування довгих елементів, найчастіше за допомогою комбінації автомобіль - причіп або транспортний засіб напівпричіп.

Попит на перевезення негабаритних вантажів все ще зростає, а високі витрати, пов'язані з реалізацією транспорту, не $\epsilon$ стримуючим фактором для клієнтів. Негабаритні вантажі, у тому числі довговантажні, як уже згадувалося, використовуються у будівельній галузі, у всіх виробничих та промислових видах діяльності, енергетиці, охороні навколишнього середовища та багатьох інших сферах

Перевезення негабаритних вантажів стає все більш популярним, що пов'язано, зокрема, з будівництвом вітрових електростанцій для виробництва електроенергії в гірських районах або на узбережжі Балтійського моря. Мережі Iнтернеткомунікацій розширюються, що вимагає будівництва нових релейних башт. Транспортувати нероздільні елементи стає все довше і важче доставляти та встановлювати на місцях. Все це має бути задоволено шляхом експедування та транспортування промислових довгомірних вантажів. Така ситуація вимагає спеціалізованих транспортних засобів, моніторингу та оптимізації маршрутів подорожей.

Ключові слова: негабаритні вантажі, транспортні засоби, напівпричепи, логістичні системи, економічні аспекти, юридичні аспекти.

\section{Introduction}

All activities related to the transfer of a tangible good, together with all the processes of planning and controlling the transfer of this good, define the concept of logistics. It is important to support the logistics process with computer software, which is mainly based on the GPS system. One of the elements of the process of transferring goods in logistics is the transport services. It would be impossible to carry out shipping without the transport services.

Transport of long goods is carried out with the help of vehicles structurally and equipped to transport long elements, most often using a vehicle-trailer or vehicle-semi-trailer combination. According to the Norm PN-93 D02002 Wood Raw Material Classification (Klasyfikacja surowca drzewnego), log is round, large-size wood with a minimum diameter of $20 \mathrm{~cm}$ and a minimum length of $9.0 \mathrm{~m}$ for conifers and $6.0 \mathrm{~m}$ for deciduous species. The specific type of this type of cargo determines the method of loading and transport, and to facilitate operations, various types of devices and vehicles are used [1]. Currently, the concept of logs is also used for long industrial products, i. e. columns, tower elements, power windmills, and girders of factory halls. 
The transport of oversize cargo is an important segment of the transport services market. Despite many inconveniences and difficulties, the oversized cargo is becoming more and more common. It is influenced by the development of the economy and the growing demand for the transport of non-standard loads. Due to the specificity, these transports are comprehensive logistic, forwarding, and transport services [2]. The implementation of the transport service requires not only the involvement of specialized equipment, but it is also several organizational processes such as:

- transport supervision,

- piloting,

- technical support during the entire transport,

- obtaining the necessary arrangements,

- obtaining permits for the performance of transport.

The demand for the transport of oversized cargo is still growing, and the high costs associated with the implementation of the transport are not a deterrent for customers. The oversized cargo, including long cargo, as already mentioned, are used in the construction industry, all production, and industrial activities, energy, environmental protection, and many other areas [3].

Analysis of research and publications. The level of development of transport infrastructure, the degree of efficiency of using transport are important factors in the development of an enterprise, a region, and a country (O. Chukurna [4], N. Havrylenko [5, 6], M. Oklander [7], A. Ostenda [8]), as well as factors of supporting European integration processes (T. Zubro [9]). The work of Ukrainian and foreign researchers was devoted to determining the optimal parameters in the organization of transport (T. Nestorenko, M. Morkunas, J. Peliova [10], S. Zeng, O. Nestorenko [11]). The transport of oversized cargo is received so much attention from foreign scholars, such as J. Rybicski, D. Chojnacki [3], S. Juњcicski, D. Marciniak-Neider [15], E. Januia, T. Truњ, Ï. Gutowska [12], J. Neider [13], E. Mendyk [14], and others.

The main purpose of the article is to study deals with the transport of non-standard loads, and above all, long ones.

Presentation of the main research material. One of the main aspects of organizing the transportation of goods by oversized vehicles is the legal aspect. Let's consider oversized transport according to legal acts.

Oversized loads, also known as XXL loads, are loads whose movement requires the use of special means of transport and handling equipment [13] because one of their features or combinations does not allow the use of standard transport solutions. According to E. Mendyk, non-standard loads are loads whose shape exceeds the dimensions of the vehicle [14]. J. Neider supplements the above definition by stating that oversize loads require the use of special instruments of transport and handling equipment, which distinguishes them from standard loads [13]. The issue of oversized cargo transport was raised in the Act of 20 June 1997 - Road Traffic Law (Prawo o Ruchu Drogowym), which defines an oversize vehicle, which is a vehicle or a combination of vehicles, the axle loads of which, with or without a load, are greater than the permissible loads provided for a given road in the regulations on public roads, or whose dimensions or actual total weight, with or without a load, are greater than the permissible [16]. In the light of Polish law, a load may be considered abnormal if, during transport, it causes the set to exceed at least one of the parameters [15]:

- length $(16.5 \mathrm{~m})$;

- width $(2.55 \mathrm{~m})$, with the exception of the refrigerated box $(2.6 \mathrm{~m})$;

- height $(4.0 \mathrm{~m})$;

- actual total weight $(40 \mathrm{t})$;

- axle load $(10 \mathrm{t})$.

According to the Law on Road Traffic Law, traffic with a pressure of a single drive axle to $11.5 \mathrm{t}$. is permitted on public roads. It corresponds to the majority of domestic roads [16]. Vehicles with a single axle load of up to 10 tons may drive on voivodeship roads and some domestic roads. The remaining road categories allow the movement of vehicles with a single axle load of up to $8 \mathrm{t}$. The limitations of the load capacity result from the road structure and the maximum load that is provided for a given road section. In order to protect road traffic safety, property, infrastructure and the loads themselves, the legislator has created a number of legal provisions that define the conditions and procedures for performing journeys. According to the previously presented act, traffic on public roads of transport carrying oversize cargo is possible, provided that the entity providing the transport service meets a number of conditions, including obtaining an appropriate permit, which is issued by an administrative decision by the competent authority [13].

The permits are issued in seven categories, depending on the exceedance of individual standards for dimensions, weight, or axle loads by vehicles. The subject of travel permits was included in the Regulation of the Minister of Transport, Construction and Maritime Economy of June 23, 2012 on permits for the passage of nonstandard vehicles. The regulation also specifies the validity period of the permits and the costs related to their issuance.

Table 1 contains a list of all categories, together with the authorities authorized to issue a given permit, validity dates, fees and the specification of roads on which a given oversize passage may be performed. Obtaining a permit for the passage of an abnormal vehicle takes place at the request of the interested party performing the journey after meeting several requirements and paying the fee. 
Another important legal act regulating the passage of non-standard transports is the Regulation of the Minister of Transport, Construction and Maritime Economy of 23 May 2012, regarding the piloting of non-standard vehicles. This act defines, among others, conditions of piloting, technical conditions of the vehicle performing the piloting, marking used during the piloting process as well as the duties and powers of the pilot during the oversight process.

Table 1

Categories of permits for oversized vehicles

\begin{tabular}{|c|c|c|c|}
\hline Category permission & \multirow{2}{*}{ Oversized vehicles - parameters } & \multirow{2}{*}{ Roads } & \multirow{2}{*}{ Expiry date and fees } \\
\hline Issuing authority & & & \\
\hline Category I & \multirow{2}{*}{$\begin{array}{l}\text { - with dimensions and real total weight } \\
\text { not greater than the permissible ones, } \\
\text { - with an axle load not exceeding the size } \\
\text { provided for roads with a permissible axle } \\
\text { load of } 11.5 \text { tons }\end{array}$} & \multirow{2}{*}{$\begin{array}{c}\text { communal, } \\
\text { county, } \\
\text { provincial } \\
\text { indicated in the permit. }\end{array}$} & \multirow[b]{2}{*}{$\begin{array}{c}1 \text { month: } 50 \text { PLN } \\
6 \text { months: } 100 \text { PLN } \\
12 \text { months: } 200 \text { PLN }\end{array}$} \\
\hline $\begin{array}{l}\text { The road manager } \\
\text { responsible for the road }\end{array}$ & & & \\
\hline Category II & \multirow{2}{*}{$\begin{array}{l}\text { - of length, height and actual total weight } \\
\text { not greater than the permissible, } \\
\text { - with axle loads not greater than the } \\
\text { permissible for a given road, } \\
\text { - with a width not exceeding } 3.5 \mathrm{~m}\end{array}$} & \multirow[b]{2}{*}{$\begin{array}{l}\text { public, except } \\
\text { expressways and } \\
\text { motorways }\end{array}$} & \multirow[b]{2}{*}{12 months: 100 PLN } \\
\hline Staroste & & & \\
\hline Category III & \multirow{2}{*}{$\begin{array}{l}\text { - with axle loads and real total mass } \\
\text { not greater than the permissible, } \\
\text { - a width not exceeding } 3.2 \mathrm{~m}, \\
- \text { of a length not exceeding } \\
15 \mathrm{~m} \text { for a single vehicle and } 23 \mathrm{~m} \\
\text { for a combination of vehicles, } \\
\text { - with a height not exceeding } 4.3 \mathrm{~m}\end{array}$} & \multirow[b]{2}{*}{ public } & \multirow[b]{2}{*}{$\begin{array}{l}1 \text { month: } 200 \text { PLN } \\
6 \text { months: } 1000 \text { PLN } \\
12 \text { months: } 1200 \text { PLN } \\
24 \text { months: } 2000 \text { PLN }\end{array}$} \\
\hline $\begin{array}{c}\text { Staroste and the Head of the } \\
\text { Customs Office }\end{array}$ & & & \\
\hline Category IV & \multirow[b]{2}{*}{$\begin{array}{l}\text { - with an actual total mass not greater than } \\
\text { the permissible, } \\
\text { - a width not exceeding } 3.4 \mathrm{~m} \text {, } \\
\text { - with a length not exceeding } 15 \mathrm{~m} \\
\text { for a single vehicle, } 23 \mathrm{~m} \text { for a combination } \\
\text { of vehicles and } 30 \mathrm{~m} \text { for a combination } \\
\text { of vehicles with steered axles, } \\
\text { - with a height not exceeding } 4.3 \mathrm{~m} \text { and with } \\
\text { axle loads not exceeding the values provided } \\
\text { for roads with a permissible single axle load } \\
\text { of up to } 11.5 \mathrm{t}\end{array}$} & \multirow[b]{2}{*}{ domestic } & \multirow[b]{2}{*}{$\begin{array}{l}1 \text { month: } 500 \text { PLN } \\
6 \text { months: } 1000 \text { PLN } \\
12 \text { months: } 2000 \text { PLN } \\
24 \text { months: } 3000 \text { PLN }\end{array}$} \\
\hline $\begin{array}{c}\text { GDDKiA* and Head of the } \\
\text { Customs Office }\end{array}$ & & & \\
\hline Category V & \multirow{2}{*}{$\begin{array}{l}\text { - with axle loads not greater than } \\
\text { the permissible for a given road, } \\
\text { - a width not exceeding } 3.4 \mathrm{~m} \text {, } \\
\text { - with a length not exceeding } 15 \mathrm{~m} \\
\text { for a single vehicle, } 23 \mathrm{~m} \text { for a combination } \\
\text { of vehicles and } 30 \mathrm{~m} \text { for a combination } \\
\text { of vehicles with steered axles, } \\
\text { - a height not exceeding } 4.3 \mathrm{~m} \text {, } \\
\text { - with an actual total weight not exceeding } 60 \mathrm{t}\end{array}$} & \multirow[b]{2}{*}{ public } & \multirow[b]{2}{*}{$\begin{array}{l}1 \text { months: } 600 \text { PLN } \\
6 \text { months: } 1200 \text { PLN } \\
12 \text { months: } 2400 \text { PLN } \\
24 \text { months: } 3600 \text { PLN }\end{array}$} \\
\hline GDDKiA & & & \\
\hline Category VI & \multirow[b]{2}{*}{$\begin{array}{l}\text { - width not exceeding } 3.4 \mathrm{~m} \text { for a single } \\
\text { carriageway, } 4 \mathrm{~m} \text { for a dual carriageway of } \mathrm{A} \text {, } \\
\mathrm{S} \text { and GP class; } \\
\text { - length not exceeding: } 15 \mathrm{~m} \text { for a single } \\
\text { vehicle, } 23 \mathrm{~m} \text { for a combination of vehicles, } \\
30 \mathrm{~m} \text { for a combination of vehicles with } \\
\text { steered axles; } \\
\text { - a height not exceeding } 4.3 \mathrm{~m} \text {; } \\
\text { - with an actual total weight not exceeding } 60 \mathrm{t} \text {; } \\
\text { - with axle loads not exceeding the values } \\
\text { provided for roads with a permissible load } \\
\text { of a single driving axle up to } 11.5 \mathrm{t}\end{array}$} & \multirow[b]{2}{*}{$\begin{array}{c}\text { krajowe zgodnie } \mathrm{z} \\
\text { wykazem dryg o ktyrym } \\
\text { mowa w art. } 64 \mathrm{c} \text { ust. } 8 .\end{array}$} & \multirow[b]{2}{*}{$\begin{array}{c}1 \text { month: } 800 \text { PLN } \\
6 \text { months: } 1600 \text { PLN } \\
12 \text { months: } 3200 \text { PLN } \\
24 \text { months: } 4800 \text { PLN }\end{array}$} \\
\hline GDDKiA & & & \\
\hline Category VII & \multirow{2}{*}{$\begin{array}{l}\text { - with dimensions and actual total weight } \\
\text { greater than those listed in categories I - VI, } \\
\text { - with axle loads exceeding the values } \\
\text { provided for roads with a permissible single } \\
\text { axle load of up to } 11.5 \mathrm{t}\end{array}$} & \multirow[b]{2}{*}{$\begin{array}{l}\text { designated route } \\
\text { indicated in the permit }\end{array}$} & \multirow{2}{*}{$\begin{array}{c}500,00 \text { PLN for a single ride of a vehicle whose } \\
\text { dimensions exceed the values established for } \\
\text { categories III and IV and whose axle loads } \\
\text { and weight are not greater than the } \\
\text { permissible ones. } 1600,00 \text { PLN for a single } \\
\text { vehicle ride in other cases }\end{array}$} \\
\hline GDDKiA & & & \\
\hline
\end{tabular}

* The General Directorate for National Roads and Motorways

Source: compiled by the authors based on www.gddkia.gov.pl.

Access to the General Directorate for National Roads and Motorways website is shown on Fig. 1.

Other legal acts regulating the rules for the passage of oversized vehicles are the Regulation of the Minister of Transport, Construction and Maritime Economy of March 28, 2012, on the number of fees for issuing a permit for the passage of non-standard vehicles and the Regulation of the Minister of the Interior and Administration of December 30, 2002, in on-road traffic control. There is a division of non-normative loads into six basic groups [2]: 
1. Ordinary.

2. Special.

3. Heavy.

4. Heavy with concentrated mass.

5. Heavy spatial.

6. Long (logs).

Let's consider vehicles used in oversized transport.

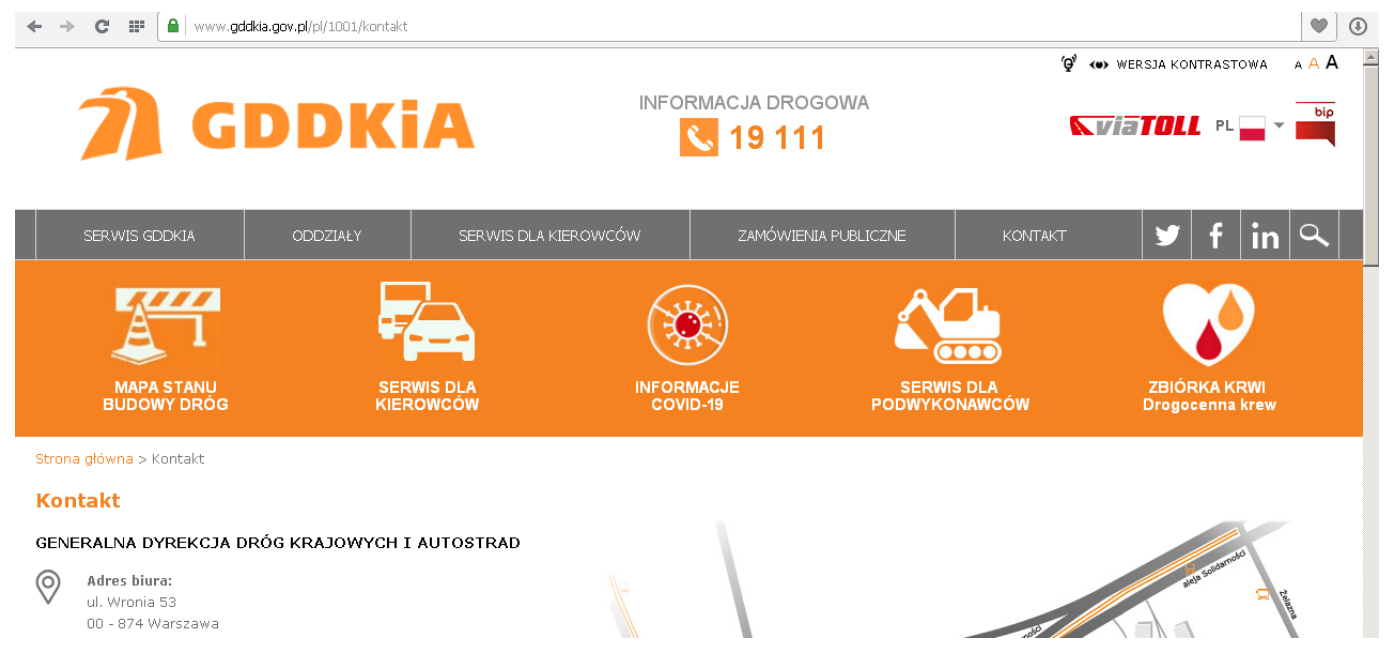

Fig. 1. The General Directorate for National Roads and Motorways (GDDKiA) website

Source: https://www.gddkia.gov.pl/p1/1001/kontakt

Heavy goods vehicles currently found on Polish roads are trucks: single vehicles, articulated vehicles, which include tractor units with semi-trailers, and vehicle combinations consisting of a truck with a semi-trailer [7]. However, a standard truck is not adapted to non-standard transports. In road transport, tractors, semi-trailers, and trailers are used to transport XXL loads [3]. The tractors used for this type of transport are tractor units and ballast tractors. Tractor units are connected to a towed element, i. e. the low-floor semi-trailer using a fifth wheel. Depending on the construction of the semi-trailer and the weight of the load, the semi-trailer rests directly in the tractor saddle or can be supported on an additional trolley. This is to distribute the weight over as many axles as possible. These tractors cooperate with semi-trailers designed for loads whose weight does not exceed $100 \mathrm{t}$ [2]. On the other hand, the power of their engines is in the range of 500-750 HP.

Ballast tractors are tractors designed to carry much heavier loads, and their engine power reaches 700 HP. These are 4 or 5 -axle vehicles with all rear wheel drive. They are equipped with a short load box and ballast in the form of concrete slabs, steel blocks, or tanks for water or sand. Tractors are used to transport loads up to 250 t. We distinguish [8]: standard semi-trailers, Mega semi-trailers, Jumbo semi-trailers, long semi-trailers, Lang semitrailers, heavy low-floor semi-trailers, recessed semi-trailers, semi-trailers for transporting tanks, semi-trailers for transporting heavy working machines, modular semi-trailers and specialized modular semi-trailers. Standard semitrailers can be typical semi-trailers with a platform length of $13.0 \mathrm{~m}$ and a height of $1.35-1.4 \mathrm{~m}$. They are used to transport small-size elements, weighing $24-25 \mathrm{t}$, up to $15 \mathrm{~m}$ long, up to $7 \mathrm{~m}$ wide and up to $2.8 \mathrm{~m}$ high. A variation of the standard semi-trailer is an extendable semi-trailer, 9-21 m long, on which long loads can be transported [6]. Mega-type semi-trailers are distinguished from ordinary semi-trailers by the height of the platform, which is located at a height of 1-1.5 m. This type of semi-trailer allows for the transport of elements up to $3.5 \mathrm{~m}$ high. The Mega-type semi-trailer has an extendable version, up to $21 \mathrm{~m}$ long (Fig. 2).

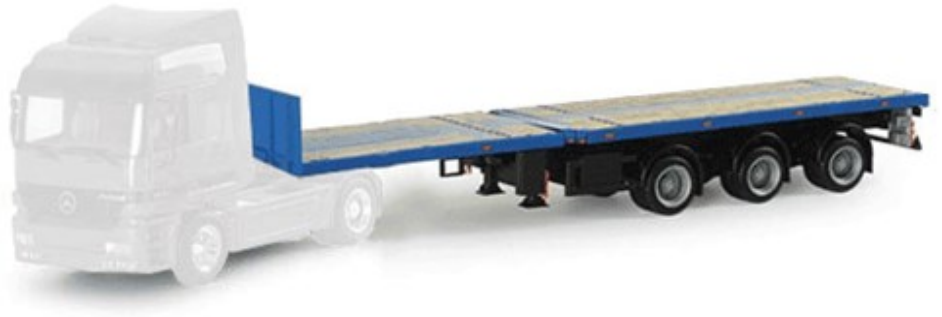

Source: www.labtrans.pl/tabor/

Fig. 2. Mega-type semi-trailer

Jumbo-type lowered floor semi-trailers are semi-trailers with a platform height of $0.75-1.5 \mathrm{~m}$. The basic length of the semi-trailer is usually $9.3-9.6 \mathrm{~m}$ loads of concentrated weight on them. Their load capacity is 25-27 tons. Jumbo semi-trailers have an extendable version with a length of about $16 \mathrm{~m}$ (Fig. 3) [6]. 


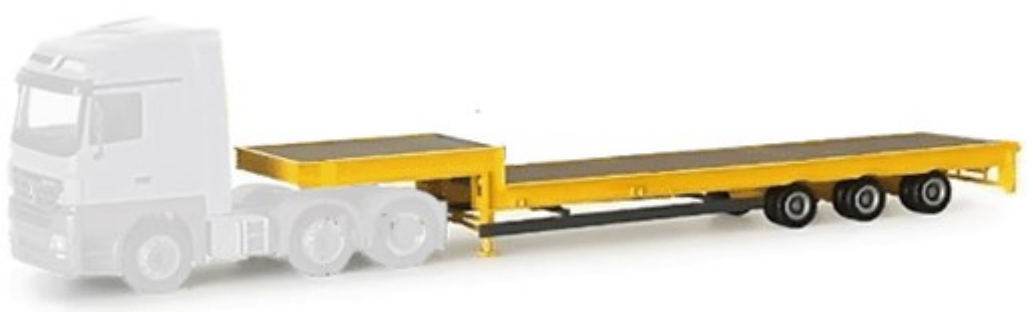

Fig. 3. Jumbo-type semi-trailer

Source: www.labtrans.pl/tabor/

Log semi-trailers resemble standard sliding semi-trailers. But their chassis are reinforced and equipped with a larger number of axles. These semi-trailers can be extended up to 36.0-45.0 m. 3- or 4-axle tractors are used for their transport. The log semi-trailer is equipped with additional, independently controlled axles. As the name suggests, these log semi-trailers are used to transport non-standard loads with large length parameters. Their load capacity depends on the number of axles and amounts to 40-50 t [6]. A variant of the log semi-trailer is the Lang-set, which consists of a tractor with the so-called "Swan neck", turntable and a trolley equipped with another turntable. This type of set (depending on the total number of axles) is able to transport long loads with a length of 50-65 m and a weight of up to about $60 \mathrm{t}$ (Fig. 4).

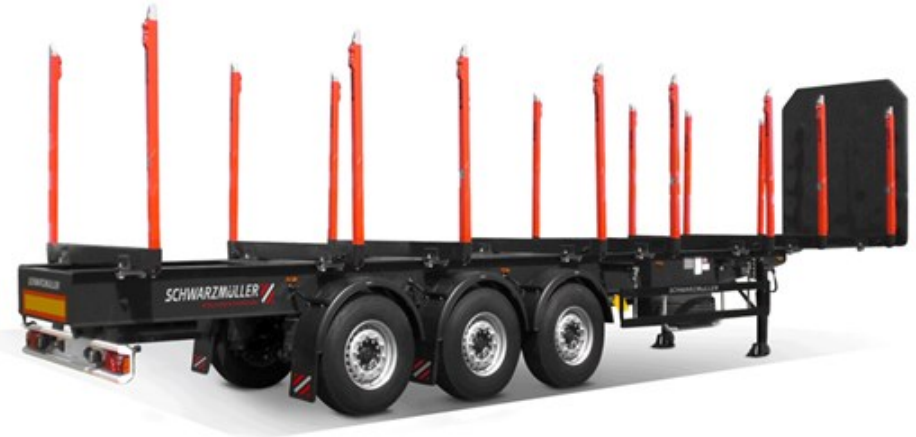

Fig. 4. Log semi-trailer

Source: http://www.trucks-machines.pl/maszyny-budowlane/dodatki/883-w-strone-lekkosci

Heavy low-bed semi-trailers are equipped with 4 or 8 axles, hydraulic or pneumatic suspension. They are coupled with 3-, 4- or 5-axle tractors. They are designed to transport loads up to 100 tons. Their extendable varieties are equipped with platforms up to $29 \mathrm{~m}$ long. The low-bed semi-trailers are also available in versions adapted to one type of cargo. In this way, we distinguish semi-trailers for transporting working machines and combines. These semi-trailers are equipped with elements enabling the entry of a given wheeled or tracked vehicle, and their platform has cavities for the wheels, which affect the stabilization of the transported type of vehicle. Semi-recessed semitrailers are designed for transporting high loads with concentrated loads. They are equipped with a floor 0.3 to $0.6 \mathrm{~m}$ high, suspended between the "swan" neck of the tractor and the semi-trailer trolley. The recessed semi-trailer with sliding floor is 14.5-15 m long. The semi-trailers for transporting tanks look like recessed semi-trailers. But instead of a floor, they have two beams, between which the transported tank is placed. These semi-trailers have an extendable multi-axle version, with air or hydraulic suspension, with independently controlled axles, which allows the transport of loads weighing up to 80 tons and a length of up to $20 \mathrm{~m}$.

In addition to those mentioned, the following are also used:

- semi-trailers for transporting heavy working machines,

- heavy modular semi-trailers intended for the transport of heavy loads with concentrated mass,

- specialized modular semi-trailers, i.e. more massive modular semi-trailers, designed to achieve greater durability of the chassis and frame.

Conclusions. The transport of oversized cargo is becoming more and more popular, which is related to the construction of, inter alia, wind farms to generate electricity in mountain areas or on the coast of the Baltic Sea. Internet communication networks are expanding, thus requiring the construction of new relay towers. Non-divisible elements to be transported are getting longer and more difficult to be delivered and installed in the field. All this must be met by forwarding and transport of industrial long cargo. Such a situation requires specialized vehicles, monitoring and optimization of travel routes.

\section{References}

1. Nielepkowicz T., Sowicski A. Transport iadunkyw diuïycowych. https://warsztat.pl/dzial/18-warto-wiedziec/artykuly/transportladunkow-dluzycowych, 57360 .

2. Juњcicski S. Logistyka transportu iadunkyw nienormatywnych, Libropolis, Warszawa 2016, s. 18.

3. Rybicski J., Chojnacki D. Przewozy ponadnormatywne w transporcie drogowym. Materiaiy dydaktyczne, op. cit., s. 7.

4. Chukurna O., Nikolaiev D. Marketing strategy of territorial branding in the context of sustainable development. VUZF Review. VUZF University. Vol. 6 No. 1 (2021), 65-78. URL: http://papersvuzf.net/index.php/VUZF/article/view/142 
5. Havrylenko N.V. Prohnozuvannia rozvytku rehioniv na pidstavi bahatofaktornykh modelei [Ekonomika. Finansy. Pravo]. Shchomisiachnyi informatsiino-analitychnyi zhurnal (Kyiv), 2013, vol. 12(1), pp. 19-22.

6. Havrylenko N.V., Hryshchenko O.V., Koshutska V.O. Retrospektyvnyi analiz dekompozytsii lohistychnykh system. Ekonomika Finansy Pravo, 2018, 5, 21-25. URL: http://efp.in.ua/uk/journal-item/208

7. Oklander M., Chukurna O., Oklander T., Yashkina O. Methodical principles to calculation information value in pricing policy in supply chains. Estudios de Economна Aplicada. 2020, № 38-3(1) URL: http://ojs.ual.es/ojs/index.php/eea/article/view/4009/4263.

8. Ostenda A., Wierzbik-Strocska M., Nestorenko T. Rynek pracy a branïa motoryzacyjna - aspekty spoieczne, ekonomiczne i edukacja. Vzdelбvanie a spolounosќ IV. Medzinбrodnэ nekonferenunэ zbornнk. Editorky : doc. RNDr. Renбta Bernбtovб, PhD., doc. Tetyana Nestorenko. Slovensko : Preљovskб univerzita v Preљove, 2019. pp. 319-225. http://dspace.bdpu.org:8080/handle/123456789/4110

9. Zubro T., Adaљkovб D. Politiko-ekonomineskije aspekty jevropejskoj integracii: opyt Slovackoj respubliki. In Actual Problems of Economics. Kyiv : National Academy of Management, 2015. ISSN 1993-6788, 2015, no. 10, pp. 19-27.

10. Nestorenko T., Morkunas M., Peliova J., Volkov A., Balezentis T., Streimkiene D. A New Model for Determining the EOQ under Changing Price Parameters and Reordering Time. Symmetry, 2020, 12, 1512. https://www.mdpi.com/2073-8994/12/9/1512.

11. Zeng S., Nestorenko O., Nestorenko T., Morkūnas M., Volkov A., Balehentis T., \& Zhang C. EOQ for perishable goods: modification of Wilsons model for food retailers. Technological and Economic Development of Economy, 2019. 25(6), 1413-1432. https://doi.org/10.3846/tede.2019.11330

12. Januia E., Truњ T., Gutowska Ï., Spedycja, Wydawnictwo Difin, Warszawa 2011, s. 167-168.

13. Neider J., Transport miкdzynarodowy, Polskie Wydawnictwo Ekonomiczne, Warszawa 2012, s. 173.

14. Mendyk E. Ekonomika i organizacja transportu, Wyïsza Szkoia Logistyki, Poznac 2002, s. 226.

15. Marciniak- Neider D., Neider J. Podrkcznik spedytora, Polska Izba Spedycji i Logistyki, Gdynia 2006, s. 494.

16. Act of June 20, 1997, Road Traffic Law - in accordance with the change introduced in the Act of August 18, 2011, amending the Road Traffic Law and other Laws (Dz. U. Nr 222 z 2011r. poz. 1321).

Paper received : 11.08.2021

Printed : 04.10.2021 